\title{
Characterization of SE-3, a Virulent Bacteriophage of Saccharopolyspora erythraea
}

\author{
By MARIA SMORAWIǸSKA, ${ }^{1} \dagger$ FRANÇOIS DENIS, ${ }^{3}$ \\ CLAUDE V. DÉRY, ${ }^{3}$ PIERRE MAGNY ${ }^{2} \ddagger$ AND \\ RYSZARD BRZEZIǸSKI ${ }^{3}$ * \\ Département de Microbiologie ${ }^{1}$ and Département d'Anatomie et de Biologie Cellulaire ${ }^{2}$, Faculté \\ de Médecine, and Département de Biologie ${ }^{3}$, Faculté des Sciences, Université de Sherbrooke, \\ Sherbrooke (Québec) J1K 2R1, Canada
}

(Received 29 December 1987; revised 7 March 1988)

\begin{abstract}
SE-3 is a virulent bacteriophage isolated from a large-scale culture of Saccharopolyspora erythraea, an erythromycin producer. The host range of the phage is narrow, limited to some strains of this species. Another strain of Sac. erythraea, and a strain of Sac. hirsuta, are able to adsorb phage particles but do not sustain their complete multiplication. SE-3 is closely related to the phage SE- 5 as shown by DNA restriction mapping. The differences between SE- 3 and SE-5 genomes are apparently limited to two DNA segments flanked by short inverted repeats, visualized by electron microscopy.
\end{abstract}

\section{INTRODUCTION}

The actinomycete Saccharopolyspora erythraea (formerly Streptomyces erythraeus) is the producer of erythromycin, a clinically important antibiotic. The phage SE-3 was isolated together with four other phages (SE-1 to SE-5) from large-scale cultures of this organism (Ostrowska-Krysiak et al., 1971; Ostrowska-Krysiak, 1974). By their morphological structure, biological and serological properties, the phages were shown to be related among themselves and to the phage 121 isolated and described earlier by Retinskaya \& Rautenstein (1960).

Phages 121 and SE-5 have a narrow host range, limited to Sac. erythraea strains, show intense cross-hybridization between their DNA and have similar restriction maps (Brzezinski et al., 1986). This 'phage family' is a good model for studies of DNA rearrangements in phage genomes. Here we describe another phage from this group, SE-3, and show that it is closely related to SE-5.

\section{METHODS}

Strains. Phages SE-3 and SE-5, as well as the strains ISP 5517 and 64-575, were provided by Drs B. OstrowskaKrysiak and A. Blonska (Institute of the Pharmaceutical Industry, Warsaw, Poland). Strains NRRL 2359, NRRL 2360, NRRL B-5616 and NRRL B-5792 were obtained from Dr A. J. Lyons (US Department of Agriculture, Northern Utilization Research and Development Division, Peoria, Ill., USA). Phage $\phi$ SE-6 and $\phi$ SE-60 DNAs were obtained from Dr C. R. Hutchinson (University of Wisconsin, Madison, Wis., USA).

Media and culture conditions; DNA extraction and analysis. The techniques used were described previously (Brzezinski et al., 1986). The G $+\mathrm{C}$ content of DNA was estimated by determination of the thermal denaturation temperature (Mandel \& Marmur, 1968) and by UV spectrophotometry (Ulitzur, 1972).

Adsorption. The adsorption rates were determined by free phage titration (Adams, 1959). Spores (108 c.f.u.) were suspended in $1 \mathrm{ml}$ fresh liquid medium (Brzeziǹski et al., 1986) supplemented with $1 \mathrm{~mm}-\mathrm{NaCl}$ and $1 \mathrm{~mm}-$ $\mathrm{Ca}\left(\mathrm{NO}_{3}\right)_{2}$, briefly $(10 \mathrm{~min})$ heat-shocked at $55^{\circ} \mathrm{C}$ and incubated at $30^{\circ} \mathrm{C}$ for $6 \mathrm{~h}$ for germination. Then, such

† Present address: Os̀rodek Badawczo-Rozwojowy Biotechnologii, Staros̀cinska 5, Warszawa, Poland.

$\ddagger$ Present address: Centre de Recherches Alimentaires, St-Hyacinthe, Québec, Canada. 
suspensions were mixed with $10^{7}$ SE-3 p.f.u. and kept at $30^{\circ} \mathrm{C}$ with gentle shaking. Samples were withdrawn every 30 min, centrifuged at 12000 r.p.m. and free phage was titrated on NRRL 2360 as indicator strain.

Electron microscopy. DNA heteroduplexes of purified SE-3 and SE-5 phages were prepared according to Davis et al. (1971), using a formamide concentration of $60 \%(\mathrm{v} / \mathrm{v})$ and a renaturation time of $90 \mathrm{~min}$, at room temperature. Photographs were taken with a Philips EM 300 electron microscope at a 12500 -fold enlargement.

\section{Plaque morphology and host range}

Phage SE-3 formed large (6-8 mm diameter) clear plaques on many different media after incubation $\left(48 \mathrm{~h}, 30^{\circ} \mathrm{C}\right)$ with either spores or mycelium of Sac. erythraea used as indicator cells. A zone of secondary growth, invading the plaque from the circumference, was seen after longer incubation (3-7d). This zone seemed to be formed by old mycelium, refractory to phage adsorption or lysis, rather than by lysogenized or resistant cells, as material taken from these areas could support phage plaque formation after liquid culture. We therefore consider SE-3 as a virulent phage.

We have determined the host range of SE-3 using five strains sent to us under the name of 'Streptomyces erythraeus', one strain of Saccharopolyspora hirsuta and 19 other Streptomyces strains. Recently, Labeda (1987) has reclassified Streptomyces erythraeus as Saccharopolyspora erythraea, and this new name is used here. However, only the strain NRRL 2338 (the new type strain) was described in Labeda's article. Among other commonly used strains cited as 'Streptomyces erythraeus' (Seno \& Hutchinson, 1986), we determined, by restriction enzyme analyses of total DNA (data not shown), that strains ISP 5517, NRRL 2359 and NRRL 2360 should also be classified as Sac. erythraea, as well as strain 64-575 from the Warsaw collection. In contrast, strain NRRL B-5616 gave a different DNA digestion pattern and, according to Labeda (1987) should be considered as a different species, designated Streptomyces labedae (Lacey, 1987).

The host range of SE-3 seems to be limited to certain Sac. erythraea strains. Among these, the highest plating efficiency was observed on strain 64-575 (Ostrowska-Krysiak et al., 1971). Plating efficiencies on the other strains, such as ISP 5517, NRRL 2360 and NRRL 2338, were between 0.8 and 0.9 . No plaques were formed on strain NRRL 2359; however, a 'clearing effect' (Prauser, 1984) was observed. The same results were also observed with Sac, hirsuta NRRL B5792. No lysis or clearing effects were observed (after plating up to $10^{9}$ p.f.u. per plate) on Str. labedae NRRL B-5616, or on the other 19 Streptomyces species.

Strains giving the clearing effect (NRRL 2359 and B-5792) adsorbed phage SE-3 with kinetics similar to NRRL 2360, which is a good host for this phage (Fig. 1). The calculated adsorption

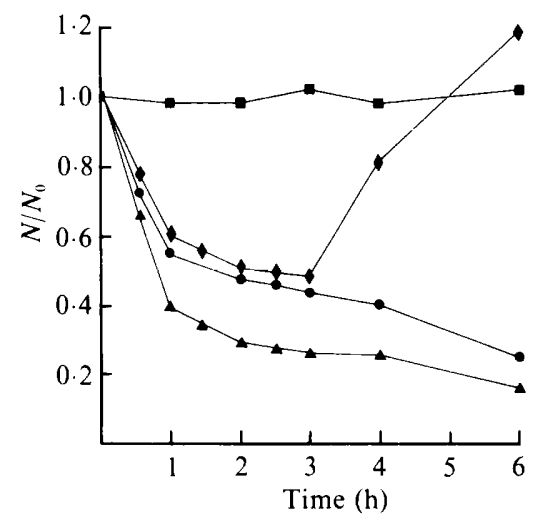

Fig. 1. Free phage titration during infection of different hosts by SE-3. $N_{0}$, phage titre before adsorption; $N$, free phage titre in each sample. Phage was added, as described in Methods, to germinated spores of : NRRL 2359 (A), NRRL $2360(\bullet)$, NRRL B-5616 (ם) and NRRL B-5792 (•). 
rates were rather low $\left(0.85-1.5 \times 10^{-9} \mathrm{ml} \mathrm{min}^{-1}\right)$ but similar to values obtained for other actinophage-host systems (Dowding, 1973). Under the same conditions, SE-3 was unable to adsorb to germinated spores of the Str. labedae strain NRRL B-5616. Viable phage progeny became noticeable after $3 \mathrm{~h}$ incubation with NRRL 2360 host cells (Fig. 1). As in plate assays, no viable progeny were detected with either NRRL 2359 or NRRL B-5792 hosts, even after $6 \mathrm{~h}$ incubation.

\section{DNA studies}

Estimation of the $G+C$ content. The $\mathrm{G}+\mathrm{C}$ content was evaluated from the thermal denaturation temperature as $58 \mathrm{~mol} \%$ (assuming that there is not extensive base modification). A slightly higher value $(60 \mathrm{~mol} \%)$ was obtained by the spectrophotometric method. The $\mathrm{G}+\mathrm{C}$ content is very similar to that of $121(59-62.5 \mathrm{~mol} \%)$ and SE-5 (57.5-59.5 mol\%) phage DNAs (Brzeziǹski et al., 1986) and quite different from that of host DNA $(70 \mathrm{~mol} \%$, Tewfik \& Bradley, 1967).

Restriction enzyme mapping. A detailed restriction map is presented for five enzymes in Fig. 2. The map was deduced from double and partial DNA digestions, except for fragments BglII-D, $\mathrm{E}$ and $\mathrm{F}$ which, being similar in size, could not be positioned by these means. We therefore subcloned the PvuII-A fragment in the SmaI site of the pUC18 vector (Yanish-Perron et al., 1985). Mapping the $B g / I I$ sites in this subclone showed that fragment $B g l I I-F$ is excluded from it and is indeed adjacent to fragment B and that fragment $B g l \mathrm{II}-\mathrm{D}$ is separated by fragments I and $\mathrm{C}$ from the fragment $\mathrm{E}$. This gave the arrangement shown in Fig. 2.

The total length of SE-3 DNA is $43.9 \mathrm{~kb}$. The linear genome is flanked by cohesive ends, as shown by the disappearance of some larger bands in restriction digests after heating $(5 \mathrm{~min}$, $80^{\circ} \mathrm{C}$ ) and quick cooling of the DNA samples (data not presented). SE-3 DNA was not cut by BamHI, XhoI, SphI, AhaIII, NcoI or SacI.

Comparison with SE-5 and other phages. The cleavage maps of SE-3 and SE-5 DNAs appear identical except for the presence of an extra $1.7 \mathrm{~kb}$ of DNA, containing a $B g l \mathrm{II}$ site, near the centre of the SE-3 map (Fig. 2). In order to obtain more precise data about the DNA rearrangements that may have occurred in this portion of the genome, the $B g l \mathrm{II}-\mathrm{C}$ and $\mathrm{E}$ fragments of SE-3, and the BglII-C fragment of SE-5 DNA, were subcloned in the BamHI site of pUC18 and more detailed restriction maps were established (Fig. 3). The additional DNA in SE- 3 compared with SE-5 is located in two segments of $1.2 \mathrm{~kb}$ and $0.5 \mathrm{~kb}$ respectively, separated by a common small segment of $0 \cdot 3 \mathrm{~kb}$.

SE-3

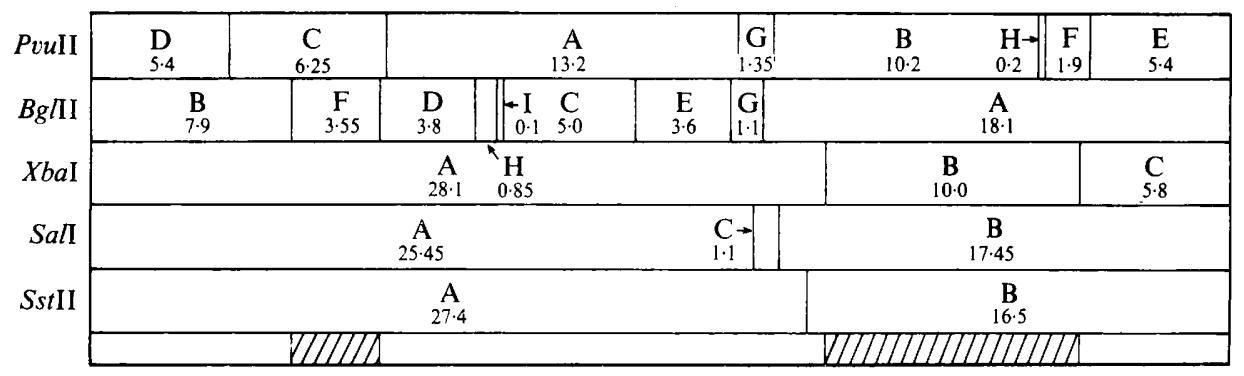

\begin{tabular}{|c|c|c|c|c|c|c|c|c|c|c|}
\hline \multirow[b]{2}{*}{ PvuII } & \multicolumn{10}{|c|}{ SE-5 } \\
\hline & $\begin{array}{r}\mathrm{D} \\
\mathrm{D}\end{array}$ & $\underset{6 \cdot 25}{C}$ & $\begin{array}{r}G \\
0.8 \\
\end{array}$ & $\underset{11.5}{\mathbf{A}}$ & & $\begin{array}{l}|\mathrm{G}| \\
1.35\end{array}$ & $\begin{array}{c}\text { B } \\
10.2 \\
\end{array}$ & $\underset{0.2}{\mathrm{H} \rightarrow}$ & $\begin{array}{c}\mathbf{F} \\
1.9\end{array}$ & $\underset{5.4}{\mathrm{E}}$ \\
\hline$B g / I I$ & $\begin{array}{r}\text { B } \\
7.9\end{array}$ & \begin{tabular}{|c|}
$E$ \\
.55
\end{tabular} & $\underset{3.8}{\mathrm{D}}$ & $\begin{array}{c}-\mathrm{H} \\
0.1\end{array}$ & $\begin{array}{c}\mathrm{C} \\
6.8\end{array}$ & \begin{tabular}{|c|}
$F$ \\
$1 \cdot 1$
\end{tabular} & & $\begin{array}{c}\mathrm{A} \\
18.1\end{array}$ & & \\
\hline
\end{tabular}

Fig. 2. DNA restriction maps of phages SE-3 and SE-5. The SE-5 map is redrawn from Brzezinski et al. (1986). Hatched bars indicate major areas of hybridization between SE-3 and $\phi$ SE60 DNA. 


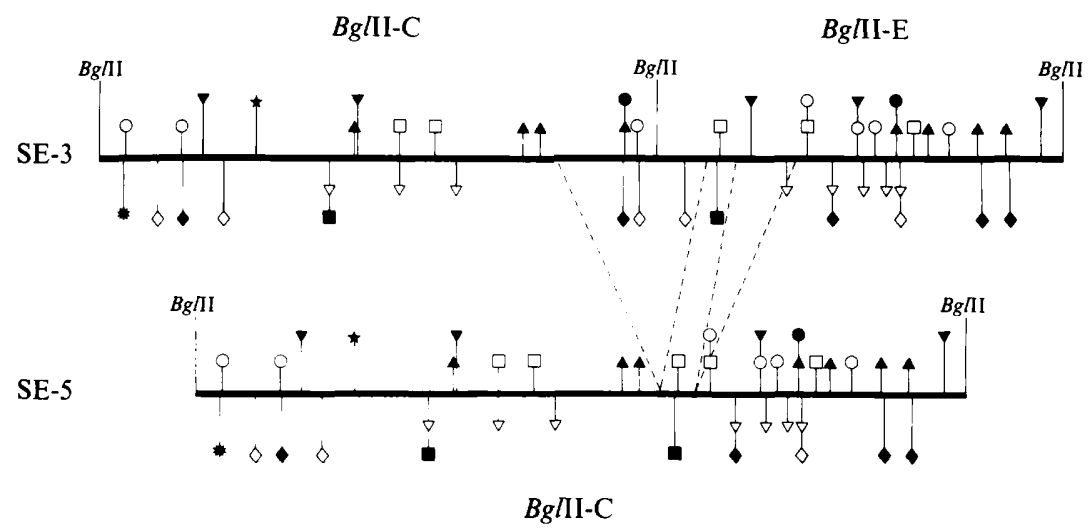

Fig. 3. DNA restriction maps of the central areas of SE-3 and SE-5 genomes. $\star$, AatII; $\square$, AvaI; $\Delta$,

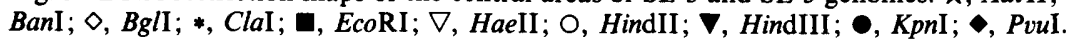

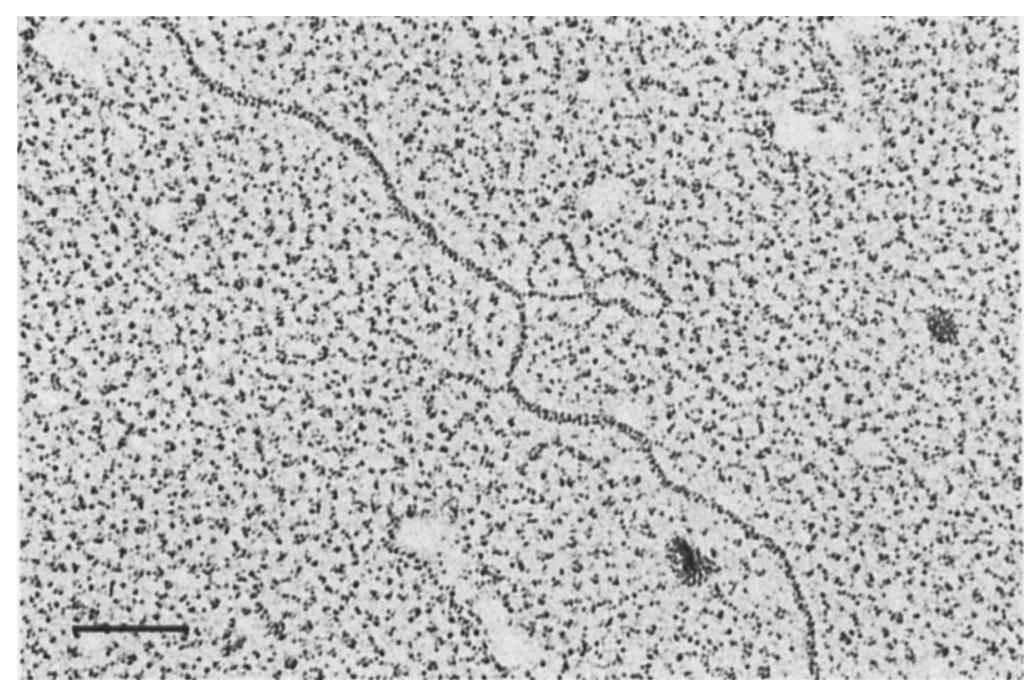

Fig. 4. Electron microphotograph of loop-and-stem structures observed in an SE-3/SE-5 DNA heteroduplex. Bar, $100 \mathrm{~nm}$.

Heteroduplex analysis by electron microscopy confirmed these findings. The two phage DNAs hybridized along their whole length (not shown), except for two single-strand loops (Fig. 4), as predicted by restriction mapping. These single-stranded segments form loop-and-stem structures, indicative of inverted-repeat DNA sequences. These repeats were estimated to be $25 \pm 5 \mathrm{bp}$ long for the bigger loop and $45 \pm 5$ bp long for the smaller loop (mean of six measurements, $\pm \mathrm{SD}$ ).

Restriction fragments of SE-3 DNA were blotted and probed with $\phi$ SE6 and $\phi$ SE60 DNAs (Grund \& Hutchinson, 1987). No homology was detected with the $\phi$ SE6 DNA probe, while some SE-3 segments hybridized with $\phi$ SE60 DNA (Fig. 2). This showed that $\phi$ SE60 was also in some way related to SE-3 (as well as phages 121 and SE-5).

\section{DISCUSSION}

Phage SE-3, with some other phages described previously (Retinskaya \& Rautenstein, 1960; Ostrowska-Krysiak et al., 1971; Ostrowska-Krysiak, 1974; Donadio et al., 1986; Grund \& 
Hutchinson, 1987), is highly specific for the erythromycin producer Sac. erythraea. The adsorption properties of this phage seem to confirm, although indirectly, the wisdom of transferring these strains from the genus Streptomyces to the genus Saccharopolyspora (Labeda, 1987). In fact, phage SE-3 and/or phages related to it were unable to adsorb on all the Streptomyces strains examined to date (this work; Brzeziǹski et al., 1986), while they were able to adsorb efficiently on germinated spores of Sac. hirsuta NRRL B-5792. This species is not very similar to Sac. erythraea but it has the same type of cell wall and the same phospholipid pattern (Labeda, 1987), which in many cases is necessary, although not always sufficient, for successful phage adsorption (Prauser, 1984). However, the phage $\phi$ SE60, related to SE-3, SE-5 and 121, is unable to form plaques on NRRL B-5792, while other phages of Sac. erythraea, such as $\phi$ SE6, $\phi$ SE45, $\phi$ SE57 and $\phi$ SE69, can develop on this strain (Grund \& Hutchinson, 1987).

The inability of the Sac. erythraea strain NRRL 2359 to support phage SE-3 multiplication cannot yet be fully explained. The observed phenomenon is best described as 'lysis from without': efficient phage adsorption; no plaque formation and severe host cell mortality (clearing effect) at high m.o.i. However, contribution of other mechanisms, such as restriction, cannot be excluded. It should be noted that the phages G3, G4 and G5 described by Donadio $e t$ al. (1986) were also unable to infect this strain. In contrast, phage $\phi$ SE-6 (Grund \& Hutchinson, 1987) was able to form plaques on this strain.

The physical structure of the SE-3 genome is very similar to that of phage SE-5. The differences are apparently limited to two DNA segments (deletions or insertions) flanked by short inverted repeats. The occurrence of some other differences, such as point mutations, or short insertions or deletions, could not, of course, be ruled out. These differences are not purely structural, but have important biological implications: phage SE-5 consistently gave 5-10-fold higher titres than SE-3 in large-scale amplification, either on Petri plates or in liquid cultures (data not shown), so we consider SE-5 as a more virulent derivative of SE-3. Furthermore, a host mutant strain, lysed by SE-5 but resistant to SE-3, has been described (Gurkau \& OstrowskaKrysiak, 1972; Ostrowska-Krysiak, 1974). This mutant is thought to be damaged in the phagereceptor systems since other related phages (SE-1 and V-II) were unable to adsorb on its cells.

The loop-and-stem DNA sequences of SE-3, visualized by heteroduplex analysis, are similar to other such 'transposon-like' structures present in actinophage (Sladkova et al., 1980; Klaus et al., 1982) or plasmid DNA (Pel'ts et al., 1983; Klaus et al., 1984). The sequence discovered in phage $\phi$ C43 DNA (Sladkova et al., 1980) was able to transpose between phage and host genomes (Lomovskaya et al., 1986). An insertion sequence, IS110, was detected in phage $\phi$ C31 derivatives after transposition from $S$. coelicolor A3(2) genomes (Chater et al., 1985; Bruton \& Chater, 1987).

The pair of phages, SE-3 and SE-5, can be considered as a starting and final point of recombinational events involving inverted-repeat sequences; therefore they furnish a model for further studies of such mechanisms as a facet of the more general problem of genetic instability in actinomycetes.

Recent experiments have extended the host range of phages 121, SE- 3 and SE-5 to the thermophilic actinomycete Faenia rectivirgula, which is able to propagate them at temperatures not exceeding $43^{\circ} \mathrm{C}$ (this laboratory and J. Schneider, Darmstadt, personal communication).

We thank Drs B. Ostrowska-Krysiak and A. Blonska for phage and bacterial strains, Dr C. R. Hutchinson for phage DNAs and for advice, and Dr A. Piekarowicz for discussions. This research was supported by a grant from the Natural Sciences and Engineering Research Council of Canada. We thank Nicole Vanasse for typing the manuscript.

\section{REFERENCES}

ADAMS, M. H. (1959). Bacteriophages. London: Interscience Publications.

Bruton, C. J. \& Chater, K. F. (1987). Nucleotide sequence of IS110, an insertion sequence of Streptomyces coelicolor A3(2). Nucleic Acids Research 15, 7053-7065.
Brzeziǹski, R., Surmacz, E., Kutner, M. \& PieKAROWICZ, A. (1986). Restriction mapping and close relationship of the DNA of Streptomyces erythraeus phages 121 and SE-5. Journal of General Microbiology 132, 2937-2943.

Chater, K. F., Bruton, C. J., Foster, S. G. \& Tobek, 
J. (1985). Physical and genetic analysis of IS110, a transposable element of Streptomyces coelicolor A3(2). Molecular and General Genetics 200, 235-239.

Davis, R. W., Simon, M. \& Davidson, N. (1971). Electron microscope heteroduplex methods for mapping regions of base sequence homology in nucleic acids. Methods in Enzymology 21, 413-428.

Donadio, S., Paladino, R., Costanzi, I., SParapani, P., SChreIl, W. \& IACCARINo, M. (1986). Characterization of bacteriophages infecting Streptomyces erythraeus and properties of phage-resistant mutants. Journal of Bacteriology 166, 1055-1060.

DowDING, J. E. (1973). Characterization of a bacteriophage virulent for Streptomyces coelicolor A3(2). Journal of General Microbiology 76, 163-176.

Grund, A. D. \& Hutchinson, C. R. (1987). Bacteriophages of Saccharopolyspora erythraea. Journal of Bacteriology 169, 3013-3022.

GURKAU, M. \& OSTROWSKA-KRYSIAK, B. (1972). Selection and characteristics of actinophage-resistant variants of Streptomyces erythraeus IA 64-575. Acta microbiologica polonica B4, 23-30.

Klaus, S., HartmanN, M., Walter, F. \& Taubeneck, U. (1982). Inverted duplication in the genome of the temperate Streptomyces phage SH3. Molecular and General Genetics 188, 322-324.

KLAUS, S., KRÜGEL, H. \& WALTER, F. (1984). Inverted repeats in the DNA of Streptomyces plasmids pMG110 and pMG120. Molecular and General Genetics 197, 143-149.

LABEDA, D. P. (1987). Transfer of the type strain of Streptomyces erythraeus (Waksman 1923) Waksman and Henrici 1948 to the genus Saccharopolyspora Lacey and Goodfellow 1975 as Saccharopolyspora erythraea sp. nov., and designation of a neotype strain for Streptomyces erythraeus. International Journal of Systematic Bacteriology 37, 19-22.

LACEY, J. (1987). Nomenclature of Saccharopolyspora erythraea Labeda 1987 and Streptomyces erythraeus (Waksman 1923) Waksman and Henrici 1948, and proposals for the alternative epithet Streptomyces labedae sp. nov. International Journal of Systematic Bacteriology 37, 458.

Lomovskaya, N. D., Muravnik, G. L., Voeykova, T. A. \& Sladkova, I. A. (1986). Functioning of IS structure in genomes of actinophages and actinomycetes. In Biological, Biochemical and Biomedical Aspects of Actinomycetes, Sixth International Symposium on Actinomycetes Biology, p. 152. Edited by G. Szabó, S. Biró \& M. Goodfellow. Budapest: Akademiai Kiado.
MANDEL, M. \& MARMur, J. (1968). Use of ultraviolet absorbance-temperature profile for determining the guanine plus cytosine content of DNA. Methods in Enzymology 12B, 195-208.

OSTROWSKA-KRYSIAK, B. (1974). Some aspects of erythromycin biosynthesis. Postepy higieny $i$ medycyny doswiadczalnej 28, 515-525.

OStrowSKa-Krysiak, B., GURKaU, M., SOKOLOWSKA, B., Sikora, D. \& BloǸSKa, A. (1971). New variants of actinophages acting upon Streptomyces erythraeus. Acta microbiologica polonica B3, 195-201.

Pel'ts, L. B., Vetoshrin, A. V. \& Sladkova, I. A. (1983). Structural features of SCP2 plasmid of Streptomyces coelicolor A3(2). Molecular Biology 17, 356-361

Prauser, H. (1984). Phage host ranges in the classification and identification of gram-positive branched and related bacteria. In Biological, Biochemical and Biomedical Aspects of Actinomycetes, pp. 617-634. Edited by L. Ortiz-Ortiz, L. F. Bojalil \& V. Yakoleff. London: Academic Press.

RetinsKaya, V. I. \& RAUTENSTEIN, YA. I. (1960). The lysogenicity of Actinomyces erythraeus cultures and the isolation of their specific actinophages. Microbiology 29, 849-855.

Seno, E. T. \& Hutchinson, C. R. (1986). The biosynthesis of tylosin and erythromycin: model systems for studies of the genetics and biochemistry of antibiotic formation. In The Bacteria, vol. IX, Antibiotic-producing Streptomyces, pp. 231-279. Edited by S. W. Queener \& L. E. Day. New York: Academic Press.

Sladkova, I. A., Chinenova, T. A., Vasilchenko, L. G., Pel'Ts, L. B. \& LomovskayA, N. D. (1980). Physical mapping of Streptomyces coelicolor A3(2) actinophages. II. A transposon-like structure in $\phi C 43$ DNA molecules and location of the region responsible for establishment of lysogenic state. Molecular Biology 14, 916-921.

TEWFIK, E. M. \& BRADLEY, S. G. (1967). Characterization of deoxyribonucleic acid from Streptomyces and Nocardia. Journal of Bacteriology 94, 1994-2000.

UlitzUR, S. (1972). Rapid determination of DNA base composition by ultraviolet spectroscopy. Biochimica et biophysica acta 272, 1-11.

Yanish-Perron, C., Vieira, J. \& Messing, J. (1985). Improved M13 phage cloning vectors and host strains: nucleotide sequences of the $\mathrm{M} 13 \mathrm{mp} 18$ and pUC19 vectors. Gene 33, 103-119. 